\title{
Konaklama İşletmelerinin Dijital Pazarlama Açısından İncelenmesi: Samsun Örneği (Examining of Accommodation Businesses in terms of Digital Marketing: Case of Samsun)
}

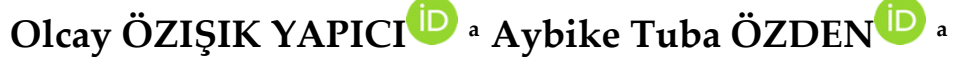 \\ a Ondokuz Mayıs Üniversitesi, Samsun Meslek Yüksekokul, Samsun, Türkiye. olcay.yapici@omu.edu.tr \\ b Ondokuz Mayıs Üniversitesi, Samsun Meslek Yüksekokulu, Samsun, Türkiye. aybike.ozden@omu.edu.tr
}

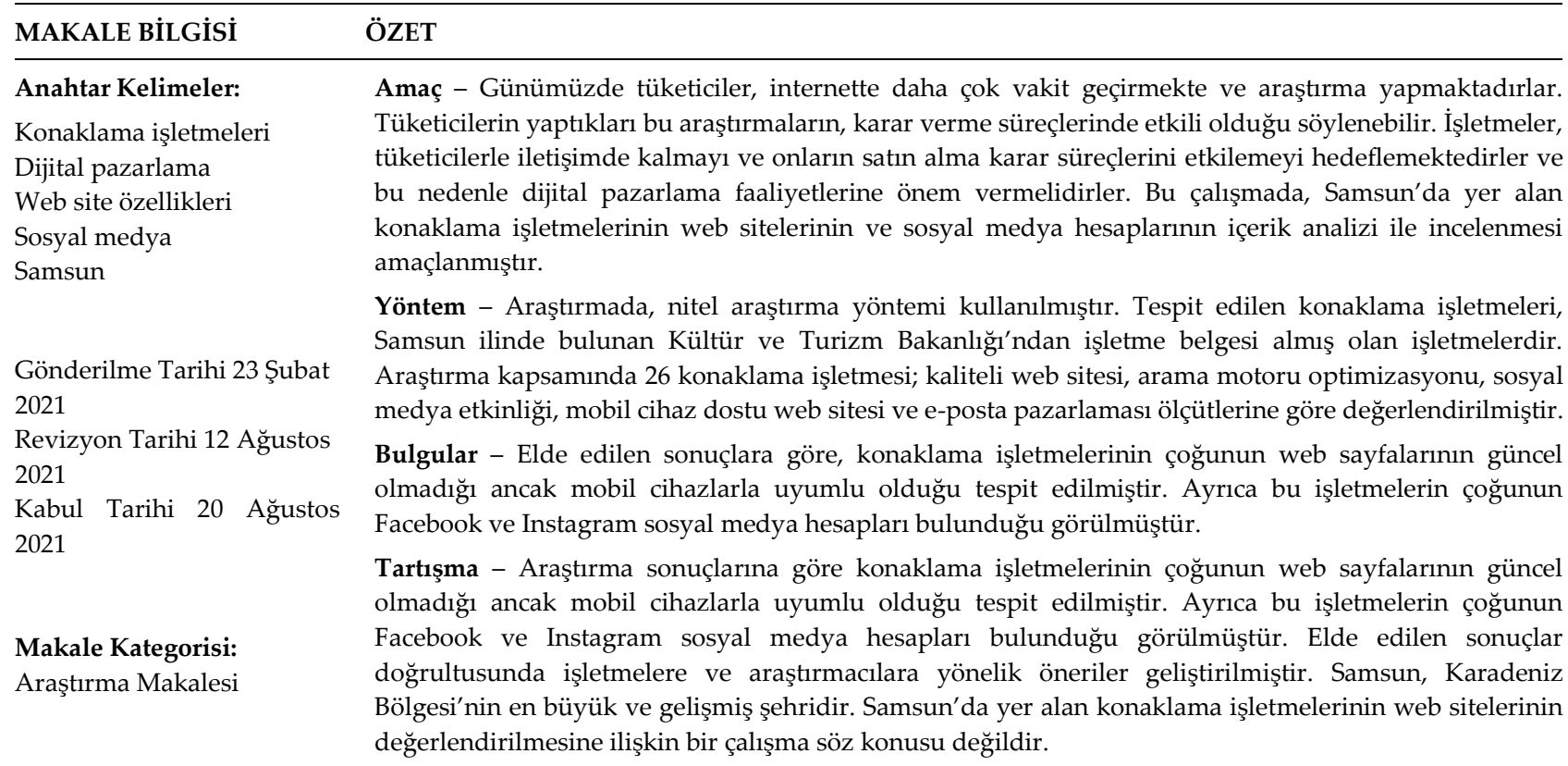

ARTICLE INFO ABSTRACT

Keywords:

Accomodation businesses

Digital marketing

Web site features

Social media

Samsun

Received 23 February 2021

Revised 12 August 2021

Accepted 20 August 2021

Article Classification:

Research Article
Purpose - Nowadays, consumers spend more time and research on the internet. It can be said that these researches made by consumers are effective in purchasing decision processes. Businesses aim to stay in touch with consumers and influence their purchasing decision processes and therefore should attach importance to digital marketing activities. In this study, it is aimed to examine the websites and social media accounts of the accommodation businesses in Samsun by using a content analysis.

Design/methodologylapproach - In the research, qualitative research method was used. The determined accommodation businesses are those that have received a business certificate from the Ministry of Culture and Tourism in Samsun. Within the scope of the research 26 accommodation establishments were evaluated according quality website, search engine optimization, strong social media presence, mobilefriendly and e-mail marketing criteria.

Result - According to the results, it has been determined that the web pages of most of the accommodation businesses are not up to date but are compatible with mobile devices. In addition, it has been observed that most of these businesses have Facebook and Instagram social media accounts.

Discussion - Suggestions for businesses and researchers have been developed in line with the results obtained. Samsun is the largest and most developed city of the Black Sea Region. There is no study regarding the analysis of the web pages of the accommodation establishments in Samsun. Therefore, this study is the first in terms of its purpose and the region where it was conducted. In this context, research is important in terms of its contributions to the literature and industry. 


\section{Giriş}

Dijital kavramı günümüzde birçok alanda yer almaya başlamıştır. İçinde bulunduğumuz zaman diliminin en önemli unsuru olarak karşımıza çıkan dijitalleşme birçok sektörde etkin kullanım alanı bulmaktadır. Günlük hayatta, çalışma hayatında, sosyal hayatta insanların ilişkileri üzerinde etkili olarak önemli bir güç haline gelmiştir (Kaplan ve Haenlein, 2010: 59). Pazarlama faaliyetlerinin bilgi ve iletişim teknolojileri ile bir araya gelebilmesi için sosyal medya, cep telefonu, tablet, bilgisayar, yapay zeka, nesnelerin interneti gibi dijital araç ve tekniklere ihtiyaç duyulmaktadır (Kannan, 2017: 22). İnternetin yaygın bir şekilde kullanılmaya başlaması ile birlikte işletmeler çağın gereklerine ayak uydurmak için pazarlama ve bilgi teknolojilerini yaygın olarak kullanmaktadır (Huang ve Wang, 2013: 88). 2020 yılında dünya genelinde internet kullanan insan sayısı 4.5 milyara, sosyal medya kullananların sayısı ise 3.8 milyara ulaşmıştır. İnternet kullananları günlük ortalama 6 saat 43 dakika internette vakit geçirmektedir. 16-64 yaş arası internet kullanıcılarının \%80'i bir hizmet ya da mal satın almadan önce internet üzerinden araştırma yapmakta ve \%74'ü satın alma işlemi gerçekleştirmektedir (www.wearesocial.com, 2020). Dijital ortamların ve dijital araçların yaygın olarak kullanıldığı günümüzde işletmelerin de çalışmalarını dijital ortamlara taşıması gerekmektedir.

Dijital pazarlama kavramı geleneksel pazarlama yöntemleri ile birlikte dijital pazarlama kanalları ve dijital pazarlama araçlarının kullanımı ile mal ya da hizmetlerin pazarlanması olarak tanımlanmaktadır (Kannan, 2017: 23). Dijital pazarlama çalışmalarında tüketicilere mobil uygulamalar, sosyal medya hesapları, video paylaşım siteleri, bloglar, web siteleri gibi çok çeşitli dijital ortamlarda tanıtım ve reklamlarını ulaştırabilmektedirler (Chaffey ve Smith, 2013: 504; Yalçınkaya, 2018: 204). Dijital pazarlamanın gerçekleştirildiği sektörlerden biri de kuşkusuz turizm sektörüdür. Turizm sektörü her ne kadar emek yoğun bir sektör olarak görülse de her geçen gün teknolojik yenilikler, dijital araçlar bu sektörde yer almaya başlamıştır. Özellikle konaklama işletmeleri ürünlerinin özelliklerini turistlere ulaştırabilmek amacıyla pazarlama faaliyetlerini dijital ortamlarda gerçekleştirmektedir. Konaklama işletmelerinin dijital pazarlama çalışmaları ile birlikte konaklama işletmesinin performansını olumlu olarak etkilediği, Belçika' da konaklama işletmeleri üzerine gerçekleştirilen bir araştırmada dijital pazarlama stratejileri aracillğ̆ ile çevrimiçi yorum ve değerlendirmelerin artış göstermesiyle birlikte konaklama işletmelerinin de performansını etkilediği sonucuna ulaşılmıştır (De Pelsmacker, Tilburg ve Holthof, 2018).

Turistlerin internet kullanımındaki amaçlar arasında seyahat etmeden önce destinasyon hakkında bilgi sahibi olmak yer almaktadır. Dolayısı ile konaklama işletmelerinin sahip olduğu mal ve hizmetleri web sitelerinde sunumu önem arz etmektedir. Web siteleri konaklama işletmelerinin sadece mal ve hizmetlerini sunma amacıyla kullanılmamakta diğer taraftan daha fazla müşteriye ulaşarak gelirlerini artırdıkları bir mecra olarak karşımıza çıkmaktadır (Akıncılar ve Dağdeviren, 2014: 264). Konaklama işletmelerinin web sayfalarının incelenmesine yönelik çok sayıda çalışma söz konusudur (Baloğlu ve Pekcan, 2006; Haşıloğlu ve Karaman, 2006; Çubukcu, 2010). Ancak Karadeniz bölgesinin önemli bir destinasyonu olan Samsun'da yer alan konaklama işletmelerinin web sitelerinin değerlendirilmesine ilişkin bir çalışma söz konusu değildir. Bu araştırmada konaklama işletmelerinin web sayfaları ve sosyal medya hesapları incelenmektedir. Bu amaçla Samsun'da faaliyet gösteren Kültür ve Turizm Bakanlığı'ndan işletme belgesine sahip olan konaklama işletmelerinin dijital pazarlama kapsamında web siteleri ve sosyal medya hesapları içerik analizi ile incelenmektedir.

\section{Kavramsal Çerçeve}

Bilgi ve iletişim teknolojilerinin hızla gelişme göstermesiyle ve internetin yaygınlaşması ile birlikte turizm işletmelerine rekabette avantaj sağlamaktadır. Teknolojik yenilikler, turizm sektörünü doğrudan etkilemektedir. Turizm sektöründe meydana gelen dijital dönüşüm denildiğinde; yapay zeka, nesnelerin interneti, müşteri ilişkileri yönetimi gibi uygulamalar gerek turistin gerekse turizm çalışanlarının işlerini kolaylaştırmaktadır (Atar, 2020). Hizmetin, sunumun ve pazarlamanın teknoloji odaklı olarak yapılıyor olması dolayısı ile ürün ve hizmetlerin pazarlanmasında dijitalleşmeyi de beraberinde getirmektedir. Teknolojinin yoğun olarak kullanılması ile birlikte gelenekselden dijitale doğru bir değişim söz konusudur (Yıldız ve Davutoğlu, 2020).

Dijital pazarlama kavramına alan yazında bakıldığında e- pazarlama, internetten pazarlama, online pazarlama, sanal pazarlama şeklinde farklı isimler de verilmektedir (Metin, 2015:80). Dijital pazarlama kavram olarak dijital ortamlar aracıllı̆̆ ile tüketicilere internet üzerinden ses, metin, video gibi içeriklerin 


\section{O. Özışık Yapıcı - A. T. Özden 13/3 (2021) 2129-2145}

gönderilmesi sürecidir (Özmen, 2013: 365). Kırçova'ya göre (2012:24) pazarlamaya yönelik çalışmaların elektronik ortamlarda internet araçları ile gerçekleştirilmesidir. Dijital pazarlamada web-site, sosyal medya, video, e-posta, arama motoru optimizasyonu gibi faklı reklam türleri kullanılarak bir ürün ya da hizmetin tanıtımı ve satışının yapılması hedeflenmektedir (Çetinkaya ve Çelik, 2019:489). Tanımlamalardan anlaşılacağı üzere dijital pazarlamada hedef daha çok tüketiciye ürün ve hizmetler hakkında bilgi sunmak amaçlanmaktadır. Turizm sektöründe dijital pazarlama açısından başarılı olabilmek için kaliteli bir web sitesi, arama motoru optimizasyonu, elektronik posta pazarlaması, sosyal medyada yer almak, içerik ve mobil cihaz dostu olmak şeklinde tanımlanan altı kriteri yerine getirmek gerekmektedir (Kaur, 2017:72).

\subsection{Kaliteli Web Sitesi}

Web siteleri aracılığı ile internet teknolojisinden yararlanarak ticari kullanım artırılabilmektedir (Cheung ve Huan, 2002:377). Web sitesinin içeriğinde çok sayıda bileşen bulunmaktadır. Dolayısı ile web sitesinin değerlendirilmesinde çok sayıda bileşeni dikkate almak gerekmektedir. Kullanıcıların özellikleri ve çeşitliliği web sitelerinin değerlendirilmesinde dikkat edilmesi gerekenler arasında yer almaktadır. Web sitesi tasarlanırken kavramsal, işlevsel ve estetik özelliklere sahip olması gerekmektedir (Yalçın ve Bahar, 2019:292). Alan yazında yer alan çalışmalar (Bayram ve Yaylı, 2009; Karabă̆, Özgen ve Özgen, 2010; Karamustafa ve Öz, 2010; Ateş ve Boz, 2015; Yanık, 2017; Özkan ve Ulama, 2018; Unur, Erdem ve Kızılcık, 2017; Yılmaz, 2017 ) otel işletmelerinin web sayfalarını incelemişlerdir.

Türkiye' de yerli ve yabancı otel zincirlerinin web sayfalarının içerik analizi yöntemi ile incelendiği çalışmada yerli grup otellerin web sitelerinde yabancı gruplara göre daha fazla özelliğe yer vermesi ancak kullanım kolaylığı açısından yerli grubun başarısız olduğu sonucuna ulaşılmıştır (Yılmaz, 2017: 237). Baloğlu ve Pekcan (2006) tarafından Türkiye'deki 4 ve 5 yıldızlı otellerin web sayfalarının tasarım ve pazarlama faaliyetleri açısından değerlendirdiği çalışmasında web sayfalarını etkin kullanamadığı sonucuna ulaşılmıştır. Çanakkale'de bulunan 3, 4, 5 yıldızlı otellerin web sayfaları üzerine yapılan çalışmada web sayfalarının etkin bir şekilde kullanılmadığı sonucuna ulaşılmıştır (Ateş ve Boz, 2015). Karabağ ve diğ. (2010) tarafından Türkiye'de Dünya Miras Listesi'nde yer alan bölgelerdeki 3, 4, 5 yıldızlı otellerin web sitelerini etkinliği üzerine yapılan çalışmada da benzer sonuçlar elde edilmiştir. Web sitelerinde otellere ilişkin iletişim bilgileri bulunmakta ancak pazarlama konusunda etkin olarak kullanamamaktadırlar (Karabağ ve diğ. 2020).

Özkan ve Ulama (2018) tarafından Marmara bölgesinde bulunan 4 ve 5 yıldızlı konaklama işletmelerinin web sitelerinde iletişim bilgilerinin, otel ve oda fotoğraflarının, e-posta adreslerinin, dil seçeneğinin, restoran bilgilerinin yer aldığı sonucuna ulaşılmıştır. Ancak otel işletmeleri web sayfalarında döviz bilgilerine, arka plan müziğine, sıkça sorulan sorulara, online müşteri hizmetleri, geri bildirim formu ve mobil uygulamalara yer vermemişlerdir (Özkan ve Ulama, 2018).

Kaur (2017) tarafından otellerin web sayfalarının incelenmesine yönelik yapılan çalışmada adres, telefon, e-posta bilgisi, haritalı adres, markanın deneyimine ilişkin bilgi, hizmete ilişkin fotoğraflar, mekan fotoğrafları, menü ve fiyatlar, güncel olma durumu, çevrimiçi satış, bağlantı linki, yazılar ve butonlar arasında uygun boşluk kriterlerinin bulundurulması gerektiği sonucuna ulaşmıştır. Dubai'de otellerin web siteleri üzerine gerçekleştirilen çalışmada otel web site tasarım kalitesinin müşterilerin memnuniyet ve satın alma davranışı üzerinde etkili olduğu sonucuna ulaşılmıştır (Yanık, 2017). Otel işletmelerinin özellikle dijital pazarlama faaliyetleri çerçevesinde web sitelerinin tasarımına ve içeriğine daha özenli yaklaşması gerekmektedir.

\subsection{Arama Motoru Optimizasyonu (SEO)}

Arama motoru optimizasyonu, işletmelere ait olan web sitelerinin anahtar kelimeleri ile ortaya çıkan arama sonuçlarının daha iyi konumlarda yer almasına ve işleyiş olarak en makul şekilde gelişimine yönelik işlemleri kapsamaktadır (Gülten, 2019). Arama motoru optimizasyonunun amacı, web sitelerinin kullanıcıların arama motorunda yazdıkları kelimeler ile ilgi düzeyini artırarak arama sonuçlarında ilk sıralarda yer almasını sağlamaktır (Dixit ve Agarwal, 2015). Arama motoru optimizasyonunun aşamaları anahtar kelime analizi, indeksleme, sayfa içi optimizasyon ve sayfa dışı optimizasyon olmak üzeredir (Malaga, 2008).

Turizm sektörü ile ilgili olarak alan yazına bakıldığında bir gezi planlaması yapılırken, arama motoru optimizasyonunda konaklama araştırmaları ilk sırada yer almaktadır. Arama sorgularında konaklamanın yanı sıra genellikle turistik yerler ve ulaşım seçenekleri ile ilişkilendirilmektedir (Pan, 2015:80). Paraskevas, Katsogridakis, Law ve Buhalis (2011) tarafından yapılana çalı̧̧mada konaklama işletmeleri için arama motoru 


\section{O. Özışık Yapıcı - A. T. Özden 13/3 (2021) 2129-2145}

optimizasyonu kullanımı konusunda farklı bakış açıları ve değişkenlerin kullanılabileceğini, arama motoru optimizasyonu konusunda dört strateji uygulanabileceğini belirtmiştir. Analiz, planlama, uygulama ve kontrol konaklama işletmelerinin arama motoru optimizasyonu stratejisi geliştirmede kullanabileceği dört aşamalı bir yaklaşımdır (Paraskevas, Katsogridakis, Law ve Buhalis, 2011). Turistik destinasyonlar hakkında bilgi alma konusunda rama motoru optimizasyonu ön plana çıkmaktadır. Başarılı bir arama motoru optimizasyonu turizmdeki dinamiklerin derinlemesine analiz edilmesiyle ortaya konulabilir. Arama motoru, turizmle ilgili bilgi araştırmaları ve çevrimiçi turizm ilgi alanı üçlüsü arama motoru optimizasyonunun turizm pazarlamasında daha başarılı kullanımı konusunda faydalı olacaktır (Pan, Xiang, Law \&Fesenmaier, 2011: 372). Arama motoru optimizasyonunun kullanımı konaklama işletmelerinin satışlarının artmasına, web sitelerinin daha çok ziyaret edilmesine katkı sunmaktadır (Li-Hsing, Meng-Huang, Jui-Chen \& Hui-Yi, 2010).

\subsection{E-posta Pazarlaması}

E-posta pazarlaması, ticari ve ticari olmayan mesajların, e-posta adreslerinin ayrıntılı bir listesi hedeflenerek gönderilmesi olarak tanımlanabilir (Hudák, Kianičková ve Madleňák, 2017). En geniş tanımıyla, potansiyel veya mevcut müşterilere gönderilen her e-posta, e-posta pazarlaması kapsamındadır (Fariborzi ve Zahedifard, 2012). Müşterilerle yakın ilişki geliştirmek, onlara yeni teklifler hakkında bilgi vermek, promosyonları tanıtmak, markalaşmak ve rakip işletmelere karşı güçlü yönleri vurgulamak gibi amaçlarla kullanılan e-posta pazarlaması, maliyeti düşük ve hızlı bir iletişim aracıdır (Budac, 2016). Ersoy ve Gülmez'in (2013) yaptıkları çalışma sonucunda; bilgi aktarımı hızı yüksekliği, maliyetin düşüklügü ve ucuza reklam yapma olanakları nedeniyle otel işletmelerinin e-posta kullanımını daha çok tercih ettikleri görülmüştür. Otel işletmelerinin e-posta özellikleri, tüketicilerin işletme web sayfalarını ziyaret etme niyetlerini etkileyebilmektedir. Yang, Min ve Garza Baker (2019), otel işletmelerinde konaklama sonrası e-posta özelliklerinin kişiselleştirme, etkileşim ve finansal özelliklerinin müşterilerin katılım düzeylerine bağlı olarak yeniden ziyaret niyetinin önemli yordayıcıları olduğunu, tutumun ise önemli bir aracı olduğunu tespit etmişlerdir.

Günümüzde dünya çapında 3.9 milyar e-posta kullanıcısı bulunmaktadır ve 2024 yılına kadar bu rakamın 4.48 milyara çıkması beklenmektedir ve dolayısıyla, e-posta pazarlamasının gelecek vadeden bir pazarlama alanı olduğu söylenebilir (Gedik, 2020b). Istvanic, Milic ve Krpic (2017), en önemli online pazarlama unsurlarından birinin e-posta pazarlama olduğunu belirtmektedirler. Nitekim e-posta, potansiyel müşterileri ikna etmek ve kısa sürede işletmenin satış potansiyelini arttırmak için kullanılabilecek online araçlardan biridir (Yavuz ve Haseki, 2012). 2004 yılında Türkiye'deki otellerin \%91'inin e-posta sahibi olduğu, 2016 yılında ise otel zincirlerinin hepsinin e-posta dahil iletişim bilgilerini müşterileri ile paylaştıkları görülmektedir (Can vd., 2017). Tüketiciler, otel işletmelerinden bilgi talebinde bulunurken kişisel verilerini işletmelerle paylaşabilmektedirler. O'Connor (2008) yapmış olduğu araştırma sonucunda, bir yıl boyunca birden fazla eposta hesabını izleyerek otel işletmelerin müşterilerinin kişisel verilerini kullanımları açısından etik davrandıklarını tespit etmiştir.

Otel işletmeleri ile ilgili yapılan araştırmalara bakıldığında; Murphy vd. (2003), İsviçre otelleri kapsamında yürüttükleri araştırmalarında e-posta yanıtlarını incelemişler ve müşterilerinin sorularına yanıt veren otellerin sadece \%53'ünün tüm soruları cevaplandırdığını ve her beş otelden birinin müşterilerine teşekkür etmediklerini tespit etmişlerdir. Fux vd. (2006) ise turizm ofislerine e-posta ile gönderilen bilgilendirme taleplerinin üçte birine yanıt alınmadığını belirtmektedirler. Matzler vd. (2005), e-posta sorgularına otel işletmelerinin yanıt davranışlarına ilişkin yürüttükleri araştırmalarında; yanıt oranı, yanıt süresi ve yanıtların bilgi kalitesini (bilgi derinliği) incelemişlerdir. Araştırmacılar, cevaplandırma kalitesinin büyük ölçekli otellerin küçük ölçekli otellere göre daha iyi durumda olduğunu, cevap verme kalitesi ile otellerin doluluk oranları arasında negatif yönde bir ilişki olduğunu tespit etmişlerdir (Matzler, 2005). Aksaraylı ve Özgen (2010), gizli müşteri yaklaşımı kullanılarak 908 otele bilgi talebi içeren e-posta göndermişler ve sadece 271 otelin geri dönüş yaptığını tespit etmişlerdir. Araştırmacılar geriye kalan otellerin kota aşımı veya yanlış adres nedeniyle yanıt vermediğini, bu durumun Türkiye'de e-posta yönetimine yeterli düzeyde önem verilmemesinden kaynaklandığını belirtmektedirler (Aksaraylı ve Özgen, 2010).

Bu çalışmalara bakıldığında otel işletmelerinin, e-posta pazarlama faaliyetlerinde iyileştirmelere ihtiyaç olduğu düşünülebilir. Nitekim Schegg, Murphy ve Leuenberger (2003), e-posta sorgusu kullanarak 13 uluslararası otel zincirinin; hız, kesinlik sağlama ve müşterilerinin e-postalarına zamanında cevap verebilme 


\section{O. Özışık Yapıcı - A. T. Özden 13/3 (2021) 2129-2145}

açısından zorluklar yaşadığını ve otel zincirlerinin büyüklüğüne göre bu durumun farklılaştığını tespit etmişlerdir. E-posta pazarlamasının önemi ve yaygınlığına rağmen, e-posta pazarlama programlarının etkinliğini artırmak, gelir yaratma potansiyelleri nedeniyle çoğu işletme için öncelik olmaya devam etmektedir (Lorente Páramo, Hernández García ve Chaparro Peláez, 2021).

\subsection{Sosyal Medyada Bulunma}

İnternet ve sosyal medya kullanıcıları sayısının sürekli arttı̆̆ı söylenebilir. Tüketiciler hem birbirleriyle hem de işletmelerle sosyal medya ortamlarında iletişim kurabilmektedirler. Sosyal medya pazarlaması, işletmelerin görünürlüklerini artırmak ve ürünlerini tutundurmak amacıyla sosyal medya ortamlarını kullanmaları olarak tanımlanabilir (Güçdemir, 2017).Dolayısıyla işletmeler, tüketicilerle sosyal medya ortamlarında iletişim kurarak kendi lehlerine olacak şekilde onları etkilemeye çalışmaktadırlar. Doğan, Pekiner ve Karaca (2018) yapmış oldukları araştırmada, katılımcıların otel işletmesiyle ilgili olumlu veya olumsuz fikirlerini sosyal medya ortamında paylaşma eğilimlerinin yüksek olduğunu tespit etmişlerdir. Bu nedenle otel işletmelerinin, sosyal medya ortamlarında tüketicilerle daha çok iletişim halinde kalarak olumsuz yorumların önüne geçebilecekleri düşünülmektedir.

Günümüzde sosyal medya platformları olan Facebook, Youtube, Instagram, Twitter, Foursquare veya Google Plus gibi ortamlar otel işletmeleri tarafından kullanılmaktadırlar (Çiftçi, 2016). Pazarda başarılı olabilmek ve rakip işletmelerin önüne geçebilmek için sosyal medya pazarlamasında bir adanmışlık sağlanması, zaman ve kaynakların da bu yönde kullanılması gerekmektedir (Russell, 2010). Örneğin Marriott Zincir Otelleri Facebook üzerinden müşteri bilgilendirmesi yapmaktadır, The Ritz-Carlton otelinde çalışan bir şef, müşterilerine Twitter üzerinden güne özel menü önerilerinde bulunmaktadır, Morgan Hotel ise Foursquare ile otellerin yer aldığı şehirlerdeki hava limanlarına check-in yapan kullanıcılara son dakika fırsatlarını göndermektedir (Eröz ve Doğdubay, 2012).

Tüketicilerin, artan eğitim ve gelir düzeyleri nedeniyle seyahat ve konaklama planlarını yaparlarken daha çok araştırma yaptıkları düşünülebilir. Nitekim Arat ve Dursun (2016), seyahat ve konaklama tercihinde sosyal paylaşım sitelerinin kullanımını araştırmışlar ve katılımcıların turizm amaçlı sosyal paylaşım sitelerine gün içerisinde 12 ve üzerinde ve 10-11 kez ziyaret ettiklerini tespit etmişlerdir. Sarı ve Kozak (2005) yapmış oldukları araştırmada, otel işletmelerinin aynı bölgedeki seyahat işletmelerine kıyasla internet sitelerinden tüketicilerin daha çok faydalandıklarını belirtmektedirler. Kheiri ve Nasihatkon (2015), sosyal medyanın seyahat davranışına etkisini araştırmışlar ve katılımcıların sosyal medyayı en çok ziyaret öncesinde kullandıklarını tespit etmişlerdir. Dolayısıyla işletmelerin konaklama yapacak tüketicileri sosyal medya ortamlarında etkileyebilme güçleri olduğu söylenebilir.

İşletmelerin sosyal medya ortamlarında yer almalarının yeterli olduğu söylenemez. Sosyal medyada yer alan işletmelerin dikkate almaları gereken çeşitli faktörler bulunmaktadır. Örneğin Hsu (2012), yapmış olduğu araştırmada uluslararası otel işletmelerinin, sosyal medya pazarlamasında önemli fırsatlar sunan Facebook kullanımında farklı dillerde kullanılabilecek dil destek seçeneklerini barındırmasını gerektiğini belirtmektedir. Eryılmaz ve Zengin, yapmış oldukları araştırma ile butik otellerin Facebook sayfalarında destinasyon, ortalama hava sıcaklık değerleri, döviz kurları ve takipçilere özel uygulamalarla ilgili bilgilerin eksik olduğunu tespit etmişlerdir. Bayram, Bayram ve Arıcı (2016), otel işletmelerinin Instagram paylaşımlarını incelemişler ve otellerin yiyecek-içecek temalı fotoğrafları daha çok kullandıklarını, manzara ve otel hizmetlerine ilişkin paylaşımların ikinci planda kaldığını ve fotoğraf içerikleri açısından kıyı otel işletmelerinin şehir otel işletmelerinden farklılaştığını belirlemişlerdir.

Otel işletmelerinin sosyal medya kullanım düzeylerinin artmasıyla tüketicilerin bu işletmelere yönelik satın alma niyetlerinin arttığı söylenebilir (Zengin ve Arıcı, 2017). Bu nedenle işletmeler sosyal medyaya ayırdıkları zamanı da artırmalıdırlar. Aktan (2018), yaptığı araştırma doğrultusunda turizm sektöründeki sosyal medya ortamları yöneticilerinin, sosyal medya ortamlarında tüketicilerin harcadıkları zaman kadar zaman harcamaları gerektiğini belirtmektedir. Alagöz ve Dereli (2020), kış turizmi otel işletmelerinin sosyal medya ortamlarını kullanımlarına ilişkin yaptıkları araştırmada, Facebook sosyal medya uzmanlarının günde 1-2 içerik paylaşılması önerisine rağmen bu otellerin genellikle gün aşırı paylaşım yaptıkları sonucuna ulaşmışlardır. Ayrıca butik otel işletmeleri, web sayfalarını ve sosyal medya ortamlarını; reklam, kişisel satış ve halkla ilişkiler gibi geleneksel pazarlama iletişimi amaçlı kullanmaktadırlar (Türker ve Türker, 2017). Bu doğrultuda işletmelerin, günümüz pazarlama anlayışı doğrultusunda tüketicilerle sürekli etkileşimde 
kalmalarının pazarlama faaliyetlerindeki başarılarına etki edeceği düşünülmektedir. Nitekim sosyal medya, günümüzde fazlasıyla etkileşimin olduğu ortamlar yaratmaktadır.

\section{5. İçerik}

İçerik, online ortamda yer alan platformların ihtiva ettiği her şey olarak tanımlanabilir. İçerik, online pazarlamanın özüdür (Kaur, 2017). Etkileyici ve dikkat çekici bir içerik, tüketicileri online ortamda istenilen platforma çekebilmek ve etkileşimi sağlayabilmek için önem taşımaktadır. Otel yöneticileri online ortamda en çok sosyal medya, kurumsal web siteleri, uygulamalar ve Google reklam araçlarından faydalanmaktadırlar (İnce ve Doğantan, 2020). Dolaysıyla işletmeler bu ortamlarda içerik üreterek tüketicilerle etkileşimde kalmalıdırlar. Günümüz pazarlama anlayışının temeli olan hedef kitleyi tanımak, isabetli içeriklerin oluşturulabilmesinin temelini oluşturmaktadır. Örneğin Liao, Proctor ve Salvendy (2008), yapmış oldukları araştırma ile online ortamda içeriklerin kültürel farklılıkları göz önüne alınarak üretilmesi gerektiği sonucuna ulaşmışladır.

Online platformlarda işletmelerin yayınladıkları içerikler; katılımcıların ziyaretini arttıracak nitelikte, doğru zamanlamada ve işletme ile ilişkili olmalıdırlar (Kaur, 2017). İçerik yönetimi günümüzde profesyonellik gerektiren bir alandır. Bu nedenle içeriği geliştirmek, zenginleştirmek ve farklılaştırmak bir pazarlama yönetimi olarak kabul edilmelidir (Özgen ve Doymuş, 2013). Fogli vd. (2010), işletmelerin en iyi içeriği ve en iyi sunumu bağımsız olarak seçmelerinin imkânsız olduğunu, etkili kullanıcı-sistem etkileşiminin yalnızca içerik özelliklerinin ve sunum alternatiflerinin ortak bir değerlendirmesiyle elde edilebileceğini yapmış oldukları araştırma ile tespit etmişlerdir.

Markalar, online ortamların sağladığı avantajlar ile kişiselleştirilmiş içerikler oluşturarak rakip işletmelerden farklılaşabilmektedirler (Kallier, 2017). Online ortamda ürünle fiziksel temasın sağlanamaması bir engel gibi görünebilir ancak hizmet sektöründe dokunulmaz olanı tüketicilere anlatabilmek bir avantaj olabilir (Arıker, 2012). Örneğin Suh ve Chang (2006), online mağazalarda ürünün web üzerinden deneyimlenmesini sağlayan sanal gerçeklik etkinliklerinin tüketicilerin; ürün bilgisini, tutumlarını ve satın alma niyetlerini artırdığını ve doğrudan veya dolaylı olarak çevrimiçi ürün bilgileri ile gerçek ürünler arasındaki ürün riski ve tutarsızlıklara ilişkin tüketicinin algısını azalttığını belirtmektedirler.

Cıngı (2015), yapmış olduğu araştırmada yüksek takipçisi olan profillerin daha çok içerik oluşturduklarını ve profillerin genellikle fotoğraf sitesi, online alışveriş sitesi, portal veya derginin profili olduğunu tespit etmiştir. Araştırmacı işletmelerin, çok takipçisi olan kullanıcıları kendileri için içerik üretmeye teşvik etmeleri gerektiğini belirtmektedir. Nitekim online ortamda üretilen içeriklerin niteliği kadar niceliğinin de önemli olduğu düşünülmektedir. Chiang (2003), otel işletmelerinin web sitelerinde en sık paylaşılandan en az paylaşılana doğru sırasıyla temel bilgiler, e-ticaret, promosyonlar, ikincil bilgiler, hizmetler ve teknoloji şeklinde olduğunu belirtmektedir.

Kaur (2017) işletmelerin içerik üretirken bu içeriğin \%20'sinin marka tanıtımına, \%80'ninin tüketicilerle etkileşim oluşturabilecek konulara ayrılması gerektiğini belirtmektedir. Nitekim ticari olmayan veya dolaylı olarak ticari olan ve kişisel bir paylaşım olarak algılanan iletişim uygulamaları, reklam içeriklerine göre daha etkilidir (Petrescu ve Korgaonkar, 2011).

\subsection{Mobil Cihaz Dostu Olmak}

Tüketicilerde satın alma isteği uyandırmak için mobil cihazlar üzerinden yapılan pazarlama faaliyetlerine mobil pazarlama denmektedir (Karaca ve Gülmez, 2010). Kaur (2017), dünyada diş firçası sahibi olan tüketicilerden daha çok mobil cihaz sahibi olduğunu belirtmektedir. Bu durum, pazarlama faaliyetlerinde mobil cihaz dostu olma zorunluluğunun bir göstergesi olarak düşünülebilir. Tüketicilerle iletişimde kalabilmenin önemli yollarından birinin mobil cihaz dostu işletme olabilmek olduğu düşünülmektedir.

Turizm sektöründe kullanılan Booking.com, Tripadvisor ve Skyscanner gibi uygulamalar, kullanıcılarında tatil öncesi, esnası ve sonrasında çeşitli avantajlar sunmaktadır (Güzel ve Başaran, 2019). Günümüzde büyük turizm işletmelerinin kendi mobil uygulamaları olduğu görülmektedir (Sürücü ve Bayram, 2016). Wang vd. (2016), otel işletmelerinin kendi uygulamalarını kullanan tüketicilerin bu uygulamaları daha çok rezervasyon ve sadakat programları için kullandıkları sonucuna ulaşmışlardır. Yapılan bir araştırmada otel yöneticilerinin yarıdan fazlasının pazarlama faaliyetleri için belirledikleri bütçenin bir kısmını mobil pazarlama için 


\section{O. Özışık Yapıcı - A. T. Özden 13/3 (2021) 2129-2145}

ayırdıkları görülmektedir ve 2012 yılı itibariyle son dakika oda rezervasyonlarının ve otel giriş işlemlerinin yapıldığı uygulamalar geliştirilmiştir (Şanlı̈̈z, Dilek ve Koçak, 2013).

Bilici vd. (2018), yapmış oldukları araştırma ile tüketicilerin mobil pazarlama mesajlarını ve kısa mesajları ürünlerle ilgili önemli bir bilgi kaynağı olarak gördüklerini belirtmektedirler. Şahin ve Cıbıt (2016), seyahat acentası müşterileri ile yürüttükleri çalışmalarında tüketicilerin mobil pazarlama algıları ile online alışveriş eğilimleri arasında pozitif yönde bir ilişki olduğunu tespit etmişlerdir. Günümüzde online alışverişin artmış olduğu düşünüldüğünde otel işletmelerinin mobil cihaz uygulamaları ile tüketicileri satın almaya ikna edebilecekleri düşünülmektedir. Nitekim mobil uygulamalar, tüketicilerin işletmelerden bilgi almalarını ve diğer tüketicilerin yorumlarını görebilmelerini sağlayabilmektedir. Saçkes ve Doğdubay (2019), tüketicilerin otel işletmelerini tercih ederlerken önceki tüketicilerin deneyimlerinden etkilendiklerini belirtmektedirler.

Adukaite vd. (2014) yapmış oldukları araştırma ile dört ve beş yıldızlı otellerin mobil uygulama içeriklerini inceleyerek en çok kullanılan mobil uygulama içeriklerinin otelin konumu, restoran menüsü ve odalar hakkında bilgi olduğunu belirtmektedirler. Chen vd. ise (2015), yapmış oldukları araştırma sonucunda mobil uygulama içeriklerinden en çok rezervasyon ve otel bilgisinin kullanıldığını tespit etmişlerdir. Bu bağlamda tüketicilerin mobil cihazlarını sürekli yanlarında taşıdıkları için konaklama planlarında karar verirlerken işletmelerin mobil uygulamalarından faydalandıkları söylenebilir. Otel işletmeleri, mobil cihaz dostu pazarlama faaliyetleriyle tüketicilerle etkileşimde kalabilirler ve seçim yaparlarken onları kendi işletmelerini seçmeleri yönünde ikna ederek pazarda güçlü kalabilirler. Örneğin Gunstock Mountain Resort Hotel mobil pazarlama ile satış artırmaya yönelik bir çalışma yürütülmüş ve dört ay boyunca sadık müşterilerini kısa mesaj ile bilgilendiren işletme önemli bir gelir elde etmeyi başarmıştır (Kılıç vd., 2017).

\section{Yöntem}

Araştırma kapsamında nitel araştırma yöntemlerinden birisi olan içerik analizi yöntemi tercih edilmiştir. Farklı türlerdeki yayın, doküman ve iletişim araçlarının içerik analizini yapabilmek mümkündür. Söylem ve öykü analizleri, mesaj analizleri, reklamlar, ilan metinleri, afişler, posterler, ders kitapları gibi çok sayıda materyal içerik analizine tabi tutulabilmektedir. İçerik analizi bir belgenin ya da bir metnin derinlemesine ve örtülü olarak içeriğinin tespit edilmesini hedeflemektedir (Arıkan, 2017). Araştırmada, çalışmanın amaçlarına uygun olarak tarama modeli kullanılmıştır. Tarama modelinde mevcut duruma müdahale etmeden, olduğu gibi betimlenmesi amaçlanmaktadır. Çalışma için toplanan veriler incelemeye konu olan başlıkları kapsamaktadır. Örnek olay tarama modeli ile yapılan araştırmalar genel tarama modeline göre daha detaylı bilgi sunmaktadır (Karasar, 2005). Çalışmada anket, mülakat, gözlem, deney gibi teknikler ile insanlar ya da hayvanlar üzerine her hangi bir durum çalışması söz konusu olmaması nedeniyle etik kurul raporu alınmamıştır.

Samsun İl Kültür ve Turizm Müdürlüğ̈̈'nün web sitesinde bulunan işletme belgeli konaklama işletmeleri çalışmanın evrenini oluşturmaktadır. İlgili web sitesinde 2021 yılı Ocak ayı itibari ile bulunan konaklama işletmesinin sayısı 30 olarak belirtilmiştir. Konaklama işletmelerinin 4 tanesinin web sitesi olmadı̆̆ından değerlendirmeye alınamamıştır. Araştırmanın örneklemi 26 konaklama işletmesinden oluşmaktadır. Örneklemde yer alan 26 konaklama işletmesi Kaur'un (2017) turizm sektöründe dijital olarak başarıyı yakalayabilmek adına tespit etmiş olduğu; kaliteli web sitesi, arama motoru optimizasyonu, e-posta pazarlaması, sosyal medyada bulunma, içerik, mobil cihaz dostu olma şeklinde altı ölçüt söz konusudur. Çalışmada söz konusu olan ölçütlerden "İçerik" başlığı değerlendirme dışında bırakılmıştır. İçerik ölçütünün değerlendirme dışında bırakılmasının nedeni ise konaklama işletmelerinin sosyal medya hesaplarında yer alan metinler, yazılar, mesajlar, görseller gibi paylaşımlar ile ilgili farklı çalışmaların farklı yöntemlerle yapılabilmesi söz konusudur. Dolayısı ile içerik ölçütü bu çalışmaya dahil edilmemiştir.

Kaur'un (2017) çalışması dikkate alınarak beş ölçüte (kaliteli web sitesi, arama motoru optimizasyonu, e-posta pazarlaması, sosyal medyada bulunma, mobil cihaz dostu olma) göre 26 konaklama işletmesinin sosyal medya hesapları ve web siteleri incelenmiştir. Konaklama işletmelerinin web sitelerine girilmiş, kaliteli web sitesi başlığı hakkında adres, telefon, e-posta bilgisi, haritalı adres olup olmadığı, marka deneyimine ilişkin bilgilerin olup olmadığı, hizmete ilişkin fotoğrafların olup olmadığı, işletmeye ilişkin fotoğrafların olup olmadığı, menünün olup olmadığı, fiyatların olup olmadığı, online satış yapılıp yapılmadığı ve online satış bağlantı adresinin olup olmadığı, görüntü, yazılar ve butonlar arasında yeterli boşluk olup olmadığı, güncellik durumu ve kaliteyi yansıtma durumlarına bakılmıştır. Arama motoru optimizasyonu yapılıp yapılmadı̆̆ı 


\section{O. Özışık Yapıcı - A. T. Özden 13/3 (2021) 2129-2145}

durumuna bakılmış ve arama motoru optimizasyonu yapan işletmelerin kaç kelime ile yaptıklarına bakılmıştır. E-posta pazarlaması başlığı altında işletmeler telefon ile aranarak müşterilerine kısa mesaj ve eposta gönderip göndermedikleri sorulmuştur. Mobil cihaz dostu web sitesi başlığ için işletmelerin web sitelerine mobil cihazlarla ulaşılmaya çalışılmış ve değerlendirmesi yapılmıştır. Sosyal medya etkinliği başlığında ise işletmelerin web sitelerinde sosyal medya hesaplarının yer alıp almadığına bakılmış ve sosyal medya hesaplarındaki veriler değerlendirilmiştir. Araştırma kapsamında bulunan konaklama işletmeleri K1, K2, K3 şeklinde K26'ye kadar kodlanmıştır. Ziyaret edilen her web sitesi ve sosyal medya hesabı için farklı değerlendirme formu kullanılmış ve web siteleri dört ölçüte göre değerlendirilmiştir. Ölçütlerin değerlendirmesi yapılırken ifadeler için var (1) ve yok (0) şeklinde kodlama yapılmıştır. E-posta pazarlaması konusunda konaklama işletmeleri telefon ile anket tekniği kullanılarak e-posta pazarlaması ve kısa mesaj kullanımı konu başlıklarında iki adet soru yöneltilmiştir.

\section{Bulgular ve Tartışma}

Araştırma kapsamında içerik analizi yöntemi ile elde edilen veriler yüzde ve frekans analizi ile incelenmiştir. Elde edilen veriler tablo haline getirilerek yorumlamaları yapılmıştır. Araştırma kapsamında yer alan konaklama işletmelerinin web sitelerinde bulunması gereken adres, telefon, e-posta bilgisi, haritalı adres, markanın deneyimine ilişkin bilgi, hizmete ilişkin fotoğraflar, mekan fotoğrafları, fiyatlar, online satı̧, online satış bağlantı linki (tripadvisor gibi), görüntü yazılar ve butonlar arasında yeterli boşluk durumu, güncelliği konusunda bilgi, kaliteyi yansıtma durumu kriterlerine göre durumları Tablo 1'de verilmiştir. Samsun'da bulunan işletme belgesine sahip konaklama işletmelerinin hepsinin web sitelerinde adres, telefon ve e-posta bilgilerine dair bilgiler yer almaktadır. Haritalı adres ise konaklama işletmelerinin 21 tanesinin web sitesinde bulunurken 5 işletmenin web sayfasında bulunmamaktadır. 25 tane konaklama işletmesinin web sitelerinde markanın deneyimine ilişkin bilgi, hizmete ilişkin fotoğraflar ve mekan fotoğrafları yer almaktadır. Samsun'da bulunan 24 konaklama işletmesinin web sayfasında menüleri yer alırken, sadece 15 işletmenin web sayfasında fiyat bilgileri yer almaktadır. Konaklama işletmelerinden 22 tanesinin web sayfasında online satış (rezervasyon) imkanı bulunurken sadece 6 konaklama işletmesinin web sayfasında online satış bağlantı linki yer almaktadır. Konaklama işletmelerinin 24 tanesinin web sitelerinin görüntü, yazılar ve butonlar arası yeterli boşluk durumu uygun görünümdedir. Web sitelerinin güncelliğine bakıldığında ise sadece 5 işletmenin güncel olduğu bilgisine ulaşılmaktadır. Web sitelerinin kaliteyi yansıtma durumuna bakıldığında ise 15 işletmenin yansıttığına, 11 işletmenin ise yansıtmadığına ulaşılmaktadır. Karabağ ve diğ. (2010) tarafından yapılan araştırma sonuçlarına göre Türkiye' deki oteller web sitelerinde genellikle adres, telefon numarası, eposta adresi, otel resimleri bulunmaktadır. Ateş ve Boz (2015) tarafından yapılan araştırma sonucunda ise konaklama işletmelerinin web sitelerini oluşturdukları ancak web sitelerini yeterinde etkin ve etkileşimli kullanmadığı, güncellemeler konusunda yetersiz kaldıkları sonucuna ulaşılmıştır.

Tablo 1. Konaklama İşletmelerinin Web Sitesinde Bulunması Gereken Unsurlar

\begin{tabular}{|l|c|c|c|c|}
\hline \multirow{2}{*}{ Web Sitesi Unsurları } & \multicolumn{2}{|c|}{ Var } & \multicolumn{2}{c|}{ Yok } \\
\cline { 2 - 5 } & $\mathrm{f}$ & $\%$ & $\mathrm{f}$ & $\%$ \\
\hline Adres, Telefon, E-posta Bilgisi & 26 & 100,00 & 0 & - \\
\hline Haritalı Adres & 21 & 80,76 & 5 & 19,24 \\
\hline Markanın Deneyimine İlişkin Bilgi & 25 & 96,15 & 1 & 3,85 \\
\hline Hizmete İlişkin Fotoğraf & 25 & 96,15 & 1 & 3,85 \\
\hline Mekân Fotoğrafı & 25 & 96,15 & 1 & 3,85 \\
\hline Menü & 24 & 92,30 & 2 & 7,70 \\
\hline Fiyatlar & 15 & 57,69 & 11 & 42,31 \\
\hline Online Satış & 22 & 84,61 & 4 & 15,39 \\
\hline Online Satış Bağlantı Linki (Tripadvisor gibi) & 6 & 23,08 & 20 & 76,92 \\
\hline Görüntü, yazılar ve butonlar arasında yeterli boşluk var mı? & 24 & 92,30 & 2 & 7,70 \\
\hline Güncelliği konusunda bilgi var mı? & 5 & 19,24 & 21 & 80,76 \\
\hline Kaliteyi yansitıyor mu? (Evet=var; Hayır=Yok) & 15 & 57,69 & 11 & 42,31 \\
\hline
\end{tabular}

Tablo 2'de 26 adet konaklama işletmesinin arama motoru optimizasyonuna ilişkin bilgiler yer almaktadır. Araştırma kapsamında yer alan konaklama işletmelerinden 7 tanesinin (K1, K2, K5, K7, K12, K15, K23) 10 ve üzeri anahtar kelime ile arama motoru optimizasyonu yapılmış web sitesine sahip olduğu belirlenmiştir. 7 
tane konaklama işletmesi ise web sitesinde 5-10 arası kelime kullanılarak arama motoru optimizasyonu yapılmıştır. 12 konaklama işletmesinin ise web sitelerinde arama motoru optimizasyonu yapmadığı tespit edilmiştir. Turizm alanındaki web sitelerinin iyi yönetilebilmesi için insanların zihnindeki anahtar kelimelerin anlaşılması önemlidir. Arama motoru optimizasyonu işletmelere web sitelerinin görünür kılmasını sağlama konusunda fayda sağlamaktadır (Vyas, 2019: 69). Li-hsing ve diğerleri (2010) tarafından yapılan çalışma sonucunda oteller web sitelerinde arama motoru optimizasyonu kullandıklarında müşterilerin telefonla işletmeyi aramalarında ve konaklama sayısında artış olduğu gözlemlenmiştir. Otel işletmelerinin web siteleri için arama motoru optimizasyonu yaptırmaları turizm sektöründe uygulanabilirliğini göstermektedir.

Tablo 2. Web Sitesi Arama Motoru Optimizasyonu

\begin{tabular}{|c|c|c|c|}
\hline $\begin{array}{l}\text { Konaklama } \\
\text { İşletmeleri }\end{array}$ & $\begin{array}{r}\text { Arama Motoru Opti } \\
\text { Sites }\end{array}$ & $\begin{array}{l}\text { zasyonu Yapılmış Web } \\
\text { Sahip }\end{array}$ & $\begin{array}{c}\text { Arama Motoru Optimizasyonu } \\
\text { Yapilma Durumu }\end{array}$ \\
\hline & $\begin{array}{c}\text { Anahtar Kelime Sayıs1 } \\
\text { 5-10 Aras1 } \\
\end{array}$ & $\begin{array}{c}\text { Anahtar Kelime Sayısı } 10 \\
\text { ve Üzeri }\end{array}$ & \\
\hline K1 & 0 & 1 & 1 \\
\hline K2 & 0 & 1 & 1 \\
\hline K3 & 0 & 0 & 0 \\
\hline K4 & 0 & 0 & 0 \\
\hline K5 & 0 & 1 & 1 \\
\hline K6 & 1 & 0 & 1 \\
\hline K7 & 0 & 1 & 1 \\
\hline K8 & 0 & 0 & 0 \\
\hline K9 & 1 & 0 & 1 \\
\hline K10 & 0 & 0 & 0 \\
\hline K11 & 0 & 0 & 0 \\
\hline K12 & 0 & 1 & 1 \\
\hline K13 & 0 & 0 & 0 \\
\hline K14 & 1 & 0 & 1 \\
\hline K15 & 0 & 1 & 1 \\
\hline K16 & 1 & 0 & 1 \\
\hline K17 & 0 & 0 & 0 \\
\hline K18 & 0 & 0 & 0 \\
\hline K19 & 0 & 0 & 0 \\
\hline K20 & 1 & 0 & 1 \\
\hline K21 & 1 & 0 & 1 \\
\hline K22 & 1 & 0 & 1 \\
\hline K23 & 0 & 1 & 1 \\
\hline K24 & 0 & 0 & 0 \\
\hline K25 & 0 & 0 & 0 \\
\hline K26 & 0 & 0 & 0 \\
\hline
\end{tabular}

Tablo 3'de araştırma kapsamında değerlendirilen konaklama işletmelerinin $\% 53,85^{\prime}$,inin e-posta pazarlaması uygulamalarını kullanmadığı tespit edilmiştir. Konaklama işletmelerinin \%57,70'i de aynı zamanda müşterilerine kısa mesaj ile bilgilendirme yapmamaktadır. E-posta pazarlaması müşterilerle daha yakın ilişkiler oluşturmak için uygun bir araçtır. Tanıtıma yönelik yapılan çalışmaların müşterilere ulaşması e-posta ya da kısa mesaj aracılığı ile daha düşük maliyet, indirim ve promosyonların dağıtımı açısından özellikle küçük ve orta ölçekli işletmeler için avantajlıdır. İzin tabanlı e- postalar, istenmeyen (spam) e postalar hakkında tüketicilerin şikayet etme durumu olması nedeniyle kullanılamamaktadır. Bu tip durumlarda alıcının onayı ile e-posta pazarlaması yapılabilmektedir (Gedik, 2020a:70). Samsun'da bulunan konaklama işletmelerinin çoğunluğunun e-posta ya da kısa mesaj ile müşterilere ulaşma durumunun düşük olmasının nedeni müşterilerin e-posta pazarlamasına onay vermemesi öngörülebilir. 
O. Özışık Yapıcı - A. T. Özden 13/3 (2021) 2129-2145

Tablo 3. E-posta ve Kısa Mesaj ile Müşterilere Ulaşma

\begin{tabular}{|l|c|c|c|c|}
\hline \multirow{2}{*}{} & \multicolumn{2}{|c|}{ Evet } & \multicolumn{2}{|c|}{ Hayır } \\
\cline { 2 - 5 } & $\mathrm{f}$ & $\%$ & $\mathrm{f}$ & $\%$ \\
\hline Konaklama İşletmelerinin Müşterilerine E-Posta ile Ulaşmaları & 12 & 46,15 & 14 & 53,85 \\
\hline Konaklama İşletmelerinin Müşterilerine Kısa Mesaj ile Ulaşmaları & 11 & 42,30 & 15 & 57,70 \\
\hline
\end{tabular}

Tablo 4'de araştırma kapsamında bulunan konaklama işletmelerinin mobil cihaz dostu web sitesine sahip olup olmadıklarına ilişkin bilgiler bulunmaktadır. Konaklama işletmelerinin \%96,15'inin web sitelerinin mobil cihazlarla uyumlu olduğu \%3,85'inin ise web sitelerinin mobil cihazlarla uyumlu olmadığı sonucuna ulaşılmıştır. Euromonitor tarafından yapılan bir araştırmaya göre akıllı telefon kullanların \% 55 'i destinasyon ile ilgili bilgi edinmek amaciyla, \%50'si ise otel ile ilgili bilgi edinmek amaciyla mobil telefonlardan seyahate çıkmadan önce yararlanmaktadır (Pınar, 2013). Şanlıöz, Dilek ve Koçak (2013) tarafından yapılan çalışmada mobil pazarlamanın da içinde bulunduğu dijital pazarlama faaliyetleri için gerekli alt yapı ve yatırımlar yapıldığında bu uygulamaların turizm işletmelerine olumlu yönde katkılarının olduğu sonucuna ulaşılmıştır.

Tablo 4. Mobil Cihaz Dostu Web Sitesi

\begin{tabular}{|l|c|c|c|c|}
\hline \multirow{2}{*}{} & \multicolumn{2}{|c|}{ Evet } & \multicolumn{2}{|c|}{ Hayır } \\
\cline { 2 - 5 } & $\mathrm{f}$ & $\%$ & $\mathrm{f}$ & $\%$ \\
\hline Web Sitesi Mobil Cihazlara Uyumu Çalışıyor Mu? & 25 & 96,15 & 1 & 3,85 \\
\hline
\end{tabular}

Tablo 5'de araştırma kapsamında yer alan konaklama işletmelerinin sosyal medya hesaplarına sahip olma durumu gösterilmektedir. Konaklama işletmelerinin \%84, 61'i facebook hesabına sahipken, \%34,62'si twitter, $\% 84,61$ 'i ise instagram hesabına sahiptir.

Tablo 5. Sosyal Medya Etkinliği

\begin{tabular}{|l|c|c|c|c|}
\hline Sosyal Medya Etkinliği & \multicolumn{2}{|c|}{ Var } & \multicolumn{3}{c|}{ Yok } \\
\hline & $\mathrm{f}$ & $\%$ & $\mathrm{f}$ & $\%$ \\
\hline Facebook & 22 & 84,61 & 4 & 15,39 \\
\hline Twitter & 9 & 34,62 & 17 & 65,38 \\
\hline Instagram & 22 & 84,61 & 4 & 15,39 \\
\hline
\end{tabular}

Türkiye'de sosyal medya kullanım durumu konusunda yapılan araştırmalar 83.88 milyon toplam nüfusa sahip olmak ile birlikte 77.39 milyon insan telefona sahip, 62.07 milyon insan ise internet kullanıcısı, 54.00 milyon insan ise sosyal medyada aktif olarak yer almaktadır. İnternet kullanan insanlar ise internette ortalama 7 saat 29 dakika vakit geçirmektedir. Sosyal medya hesaplarında geçen süre ise 2 saat 51 dakikadır. En yaygın olarak kullanılan platformlar ise Youtube, Instagram, Whatsapp, Facebook ve Twitter olarak belirtilmiştir (www.wearesocial.com, 2021). Çalışmada tamamlayıcı bilgi sağlaması adına konaklama işletmelerinin sosyal medya hesaplarının olup olmadığına bakılmış ve aynı zamanda Tripadvisor yorum sayısı ve puanları da değerlendirilmiştir.

Tablo 6'da Tripadvisor, Facebook ve Instagram ile ilgili tanımlayıcı bilgiler bulunmaktadır. Tripadvisor da en çok yoruma sahip olan konaklama işletmesi K4 işletmesidir. K4 işletmesinin 432 yorumu vardır. Aynı işletmenin ise puan 5 üzerinde $4^{\prime}$ dür. Tripadvisor' da yer alan yorumlar potansiyel müşteriler açısından önem arz etmektedir. Müşteriler daha önceki müşterilerin yorumlarını okuyup değerlendirerek işletme hakkında fikir sahibi olmaktadır. İşletmelerin facebook, instagram gibi sosyal medya hesaplarının olması müşteriler ile iletişimi kolaylaştırmanın yanı sıra farklı platformlarda müşteriye bilgi sunmaktadır. Turistik ürünün satın alınmasından önce müşteriler ürünle ilgili internetten araştırma yapmakta ve diğer müşterilerin deneyimlerinden yararlanmaktadır (Kalpaklığlu, 2015). K4 işletmesi arama motoru optimizasyonu yapılmamış, web sitesinin kalitesi konusunda kriterlerden çoğunu sağlayan ve müşterilerine e-posta ve kısa mesaj ile ulaşan bir işletmedir. Tripadvisor'da puanlamada işletmelerin 18 tanesi 4,00 ile 4,5 aralığında yer almaktadır. K4 işletmesi Tripadvisor'da Samsun ilinde turizm işletme belgesine sahip oteller arasında en çok yorum alan konaklama işletmesi olarak genel puan ortalamasında yer almaktadır.

Konaklama işletmelerinin sosyal medya kullanımı turizm sektörünün çok yönlü gelişmesine katkı sunarak bilgiye ulaşma, okuma, iletişim kurma, turizm tedarikçilerine ve destinasyonlara ilişkin bilgi paylaşımı 
O. Özışık Yapıcı - A. T. Özden 13/3 (2021) 2129-2145

sağlamaktadır. Sosyal medya kullanımı işletmelere müşteri hizmetleri, pazarlama, yeni hizmetleri tanıtma gibi çok sayıda fırsatı uygun maliyetlerle sunmaktadır (Zeylan ve Öztürk, 2019).

Tablo 6. Tripadvisor, Instagram ve Facebook ile İlgili Diğer Bilgiler

\begin{tabular}{|c|c|c|c|c|c|}
\hline \multirow{2}{*}{$\begin{array}{l}\text { Konaklama } \\
\text { İşletmesi } \\
\text { Kodu }\end{array}$} & \multicolumn{2}{|c|}{ Tripadvisor } & \multicolumn{2}{|c|}{ Instagram } & \multirow{2}{*}{$\begin{array}{c}\text { Facebook } \\
\text { Takipçi Sayıs }\end{array}$} \\
\hline & Yorum Sayıs1 & Puan & Takipçi Sayısı & Gönderi Sayı1s1 & \\
\hline K1 & 61 & 4,0 & 1.585 & 318 & 1.123 \\
\hline K2 & 195 & 3,5 & 1.214 & 489 & 1.653 \\
\hline K3 & 314 & 4,5 & 6.015 & 651 & 16.741 \\
\hline K4 & 432 & 4,0 & 3.697 & 226 & 1.067 \\
\hline K5 & 41 & 3,5 & 33,5 bin & 172 & 5.541 \\
\hline K6 & 62 & 4,0 & 569 & 28 & 679 \\
\hline K7 & 81 & 3,5 & 509 & 169 & 1.249 \\
\hline K8 & 61 & 3,0 & 45 & 4 & 412 \\
\hline K9 & 19 & 4,0 & 3.061 & 325 & 797 \\
\hline K10 & 75 & 3,5 & 9.803 & 169 & 1.436 \\
\hline K11 & 161 & 4,5 & 633 & 95 & 5.273 \\
\hline K12 & 83 & 4,0 & 4.494 & 395 & 1.226 \\
\hline K13 & 154 & 4,0 & 322 & 65 & 1.787 \\
\hline K14 & 42 & 3,5 & 6987 & 172 & 1.624 \\
\hline K15 & 8 & 4,5 & Yok & Yok & Yok \\
\hline K16 & 46 & 4,0 & 89 & 11 & Yok \\
\hline K17 & 17 & 4,0 & 1.300 & 153 & 6.682 \\
\hline K18 & 355 & 4,5 & 1.190 & 175 & 295 \\
\hline K19 & 3 & 2,5 & 1.598 & 184 & 412 \\
\hline K20 & 33 & 4,5 & Yok & Yok & Yok \\
\hline K21 & 60 & 4,0 & Yok & Yok & 364 \\
\hline K22 & 19 & 4,0 & 790 & 209 & 1.965 \\
\hline K23 & 16 & 3,0 & 4.902 & 416 & 5.716 \\
\hline K24 & 61 & 4,5 & Yok & Yok & 15 \\
\hline K25 & 56 & 4,5 & 35,1 bin & 1609 & 6.143 \\
\hline K26 & 7 & 4,5 & Yok & Yok & 929 \\
\hline
\end{tabular}

K5 işletmesinin instagramda takipçi sayısı 33,5 bin, K25 işletmesinin ise instagram takipçi sayısının 35, 1 bin olduğu görülmektedir. K5 ve K25 konaklama işletmelerinin Türkiye'deki tüm şubeler için tek bir web sitesi ve sosyal medya hesabı kullanmasından dolayı takipçi sayılarının yüksek olduğu düşünülmektedir. Özellikle K25 işletmesinin gerek takipçi sayısının yüksek olması gerek bildirim sayısının yüksek olması sosyal medya platformunun başarılı bir şekilde kullanıldığını göstermektedir.

Örneklem içerisinde yer alan konaklama işletmelerinin 4 tanesinin web sitesi üzerinden bireysel olarak rezervasyon yapma imkanı sunulmamaktadır. Konaklama işletmeleri için müşterilerin web sitesi üzerinden rezervasyon yapabilmesi rekabette önemli üstünlük sağlayacak bir uygulamadır. Günümüzde ihtiyaçların çoğunluğu internet üzerinden karşılanmaktadır. Çalışma kapsamında örnekler değerlendirildiğinde müşterilere ulaşma açısından sosyal medya hesapları başarılı olarak değerlendirilse de pazarlama açısından bakıldığında oldukça yetersiz olduğu söylenebilir. Marka bilinirliği oluşturmada kullanılacak olan yöntemlerden birisi de sosyal medya hesaplarının verimli kullanımıdır (Altındal, 2013).

\section{Sonuç ve Öneriler}

Konaklama işletmelerinin dijital pazarlama uygulamaları aracılığı ile müşteriler ile daha iyi iletişim sağlama, arama motorlarında yer alarak görünürlüğü ve marka farkındalığını artırmak, işletmelerini web sitelerini etkin kullanmak işletmelerin hedeflerine ulaşmasında önemlidir. Bu araştırma, Samsun'da faaliyet gösteren Kültür ve Turizm Bakanlığı'ndan işletme belgesi almış olan konaklama işletmelerinin dijital pazarlama 


\section{O. Özışık Yapıcı - A. T. Özden 13/3 (2021) 2129-2145}

kapsamında web sitelerinin ve sosyal medya hesaplarının içerik analizi ile incelenmesine yöneliktir. Araştırma kapsamında incelemeye alınan 26 adet konaklama işletmesi Kaur'un (2017) çalışması temel alınarak beş temel ölçüt (kaliteli web sitesi, arama motoru optimizasyonu, sosyal medya etkinliği, mobil cihaz dostu web sitesi ve e-posta pazarlaması) belirlenmiş ve işletmelerin web sayfaları ve sosyal medya hesapları bu ölçütlere göre değerlendirilmiştir.

Konaklama işletmelerinin tamamında web sayfalarında bulunması gereken özellikler olan adres, telefon, eposta bilgisi ve haritalı adres yer almaktadır. Konaklama işletmelerinin iletişim bilgilerinin web sayfalarında bulunması müşterilerin işletmelere kolay ulaşabileceğini göstermektedir. Konaklama işletmelerinin hepsinin web sayfasında markanın deneyimine ilişkin bilgiler yer almaktadır. Marka deneyimine ilişkin bilgilerin varlığı işletmelerin kendisi tarafından hazırlanmış, kuruluş yıllarının ve tecrübelerinin olduğu bilgileri kapsamaktadır. Konaklama işletmelerinin web sayfalarında ve sosyal medya hesaplarında deneyimlerini müşteriler ile paylaşması müşterilerin işletmeye karşı olan güveninin artmasını sağlayacaktır. Konaklama işletmeleri özellikle sosyal medya hesaplarını daha aktif bir şekilde kullanarak müşterilerle iletişimi daha iyi hale getirebilir. Konaklama işletmelerinin çoğunun web sayfalarının güncel olmadığı görülmektedir. Web sayfalarının güncellenmesi gerekliliği de ortaya çıkmaktadır.

Konaklama işletmelerinin büyük çoğunluğunun web sayfaları mobil cihazlarla uyumlu olarak çalışmaktadır. Web sitelerinin mobil cihazlarla uyumlu olması müşterilerin işletmelere daha kısa zamanda ve farklı mobil araçlarla ulaşabilmelerine imkan sunmaktadır.

Konaklama işletmelerinin çoğunun facebook ve instagram sosyal medya hesapları bulunmakta ve web sayfalarından sosyal medya hesaplarına ulaşım söz konusudur. Sınırlı sayıda konaklama işletmesinin twitter hesabı bulunmaktadır. Konaklama işletmelerinin sosyal medya hesaplarının varlı̆̆ı müşterilerin gerek birbirleri ile gerekse işletme ile daha çok iletişime geçebilmesine imkan sunmaktadır. Sosyal medya hesaplarının varlığı gerek işletmenin tanıtımına gerekse bölgenin tanıtımına da katkı sunmaktadır.

Araştırmadan elde edilen bulgulara göre şu öneriler sunulabilir:

$\checkmark$ Web sitelerinin optimizasyonunda yalnızca konaklama işletmesinin adı ile ilgili anahtar kelimeler değil aynı zamanda bölgenin ismi, işletmenin sahip olduğu diğer özellikler de dikkate alınarak anahtar kelimeler tespit edilmelidir. Arama motoru optimizasyonlarının ise belirli dönemlerde güncellenmesi sanal ortamda işletmeye ulaşımın kolaylaşmasını sağlayacaktır.

$\checkmark$ Günümüzde dijitalleşmenin ön plana çıkması nedeniyle konaklama işletmelerinin web sitelerini güncellemeleri, web sitelerinde sosyal medya hesaplarına yer verilmesi, sosyal medya hesaplarına ilişkin bağlantıların düzgün çalışıp çalışmadığının kontrolleri yapılmalıdır.

$\checkmark$ Konaklama işletmeleri sosyal medya hesapları aracılığı ile kendi tanıtımlarının yanı sıra bölgeye ilişkin turistik unsurların da tanıtımını yaparak, alternatif turizm türlerini tanıtma ve hatırlatma konusunda çalışmalar yapabilirler.

$\checkmark$ İşletmelerin web sitelerin mobil cihazla uyumlu olması müşterilerin mobil cihazlardan kolayca ulaşabilmesini sağlayacaktır. Müşterilerin konaklama işletmesine kolayca ulaşabilmesini sağlamak adına gerekli teknolojik altyapı desteklenmelidir.

$\checkmark \quad$ Web siteleri ve sosyal medya hesapları konaklama işletmelerinin görünen yüzüdür. Web sitelerinin güncelliği ve sosyal medya hesaplarını etkin kullanımı konusunda gerekirse alanında uzman kurum ya da kişilerden yardım almaları işletme açısından faydalı olacaktır.

$\checkmark$ Sosyal medya hesaplarında takipçi sayısının artırılması ve paylaşımların uygun zamanlarda yapılması konusunda çalışmalar yaparak daha fazla kişiye ulaşarak müşteri sayısını artırabilirler.

$\checkmark$ Konaklama işletmeleri web sitelerinde tripadvisor, trivago gibi online satış imkanı sunan web sitelerinin bağlantılarına yer vererek satışlarını artırmaya çalışabilirler.

Araştırma neticesinde sunulan öneriler günümüzde dijital pazarlama çalışması yapan ve müşterilerle iletişim kurmak isteyen tüm işletmeler için kullanılabilir önerilerdir. Konaklama işletmeleri gerek rekabet gerekse müşterilerle iletişimi sağlamak adına dijital pazarlamanın gerekliliklerini yerine getirmek durumundadır. $\mathrm{Bu}$ çalışmada sadece Samsun'da bulunan işletme belgeli konaklama işletmeleri incelenmiştir. Gelecek araştırmalarda farklı işletmeler ve bölgeler incelenebilir ve bu araştırmanın sonuçları ile karşılaştırılabilir. Çalışmada içerik ölçütü kapsam dışı bırakılmıştır. Gelecek araştırmalarda kapsamlı olarak işletmelerin web sayfaları ve sosyal medya hesaplarında paylaşılan içerikler, görseller farklı yöntemlerle incelenebilir. 


\section{Kaynakça}

Adukaite A., Reimann A.M., Marchiori E. and Cantoni L. (2013) Hotel mobile apps. the case of 4 and 5 star hotels in european German-speaking countries. In: Xiang Z., Tussyadiah I. (eds) Information and Communication Technologies in Tourism 2014. Springer, Cham, 45-57.

Akıncilar, A., \& Dagdeviren, M. (2014). A hybrid multi-criteria decision making model to evaluate hotel websites. International Journal of Hospitality Management, 36, 263-271.

Aksaraylı, M., ve Özgen, I. (2010). Otel işletmelerinin internet tabanlı müşteri ilişkilerinde e-posta yönetimi ve Türkiye'deki otel işletmeleri üzerine bir araştırma. Ege Akademik Bakış, 10(2), 727.

Aktan, E. (2018). Sosyal medyanın turizm pazarlamasındaki rolünün değerlendirilmesi. Journal of Tourism and Gastronomy Studies, 3, 228- 248.

Alagöz, G. ve Dereli, A. N. (2020). Kış turizmi koridorundaki otel işletmelerinin sosyal medya kullanımlarına ilişkin bir araştırma. Journal of Tourism and Gastronomy Studies, 8(4), 2802-2824.

Altındal, M. (2013) Dijital Pazarlamada Marka Yönetimi ve Sosyal Medyanın Etkileri, XV. Akademik Bilişim Konferansı Bildirileri 23-25 Ocak, Akdeniz Üniversitesi, Antalya.1147-1151.

Arat, T. ve Dursun, G. (2016). Seyahat ve konaklama tercihi açısından sosyal paylaşım sitelerinin kullanımı. Selçuk Üniversitesi Sosyal Bilimler Meslek Yüksekokulu Dergisi,19(41), 111-128.

Arıkan R., (2017). Araştırma Yöntem ve Teknikleri. (Gözden Geçirilmiş 3. Basım). Ankara: Nobel Yayıncılık.

Atar, A. (2020). Gelenekselden dijitale turizm sektörü. Türk Turizm Araştırmaları Dergisi, 4/2, 1640-1654.

Ateş, U. ve Boz, M. (2015). Konaklama işletmelerinin web sitelerinin değerlendirilmesi: Çanakkale örneği. Ekonomi, İşletme, Siyaset ve Uluslararası İlişkiler Dergisi, 1/1, 63-84.

Arıker, Ç. (2012). Restoran web sitelerinin içerik ve sunumlarının analizi: İstanbul örneği. Eskişehir Osmangazi Üniversitesi İktisadi ve İdari Bilimler Dergisi, 7(2), 145-172.

Baloglu, S. ve Pekcan, Y. A. (2006). The website design and internet site marketing practices of upscale and luxury hotels in Turkey. Tourism Management, 27/1, 171-176.

Bayram, M. ve Yaylı, A. (2009). Otel web sitelerinin içerik analizi yöntemiyle değerlendirilmesi. Elektronik Sosyal Bilimler Dergisi, 8/27, 347-379.

Bayram, M., Bayram, Ü., ve Arıcı, S. (2016). Otel işletmeleri instagram paylaşımlarının sosyal medya pazarlaması. ISARDER- Turk, 8 (2), 427-442.

Bilici, H., Yokuzman, N., Kılıç, B. ve Yüksel, F. (2018). Yerli turistlerin mobil pazarlama uygulamalarına karşı tutumları. Organizasyon Ve Yönetim Bilimleri Dergisi, 10(2).

Budac, C. (2016). Theoretical approaches on successful email marketing campaigns. ovidius university annals. Economic Sciences Series, 16(2), 306-311.

Çetinkaya, M. B. ve Çelik, R. (2019). Bir dijital pazarlama stratejisi olarak etkileşimli reklamların etkinliği: Deneysel bir çalışma. Uluslararası Toplum Araştırmaları Dergisi, 12/18, 484-506.

Chaffey, D. and Smith, P. R. (2013). eMarketing eXcellence: Planning and Optimizing Your Digital Marketing, New York: Routledge.

Chen, M., Knecht, S. and Murphy, H.C. (2015). An Investigation of Features and Functions of Smartphone Applications for Hotel Chains. Lugano, Switzerland.

Cheung, W. M. and Huang, W. (2002). An investigation of commercial usage of the World Wide Web: a picture from Singapore. International Journal of Information Management, 22, 377-388.

Chiang, L. C. (2003). Effectiveness of the hotel websites in singapore: a perspective from business-to-business (b2b) organisations. Asia Pacific Journal of Tourism Research, 8(2), 38-47.

Cıngı, M . (2015). Onlıne pazarlama iletişiminde kullanılan vıdeo içeriklerinin ürün tanıtımına etkisi. Humanities Sciences, $10(4)$, 145-163 
O. Özışık Yapıcı - A. T. Özden 13/3 (2021) 2129-2145

Çiftçi, H. (2016). Turistik destinasyon ürünlerinin popülerleşmesinde sosyal medyanın rolü. Akademik Sosyal Araştırmalar Dergisi, 4(33), 544-551.

Çubukcu, M. İ. (2010). Konaklama işletmeleri web site içeriklerinin değerlendirilmesi. İnternet Uygulamaları ve Yönetimi Dergisi, 1/1, 39-59.

De Pelsmacker, P., Van Tilburg, S. and Holthof, C. (2018). Digital marketing strategies, online reviews and hotel performance. International Journal of Hospitality Management, 72, 47-55.

Dixit, A., and Agarwal, M. (2015). Hybrid Approach to Search Engine Optimization (SEO) Techniques. Suresh Gyan Vihar University Journal of Engineering \& Technology 1(4), 1-5.

Doğan, M., Pekiner, A. ve Karaca, E. (2018). Sosyal medyanın turizm ve turist tercihlerine etkisi: Kars-doğu ekspresi örneği. Seyahat ve Otel İşletmeciliği Dergisi, 15(3), 669-683.

Eröz, S. ve Doğdubay, M. (2012). Turistik ürün tercihinde sosyal medyanın rolü ve etik ilişkisi. Dokuz Eylül Üniversitesi İktisadi İdari Bilimler Fakültesi Dergisi, 27 (1) , 133-157.

Ersoy, A. ve Gülmez, M. (2013). Doğrudan pazarlama araçlarının konaklama işletmelerinde kullanımı: antalya ili örneği. Anatolia: Turizm Araştırmaları Dergisi, 24 (1) , 23-40 .

Eryılmaz, B. ve Zengin, B. (2014). Butik otel işletmelerinin sosyal medya kullanımına yönelik bir inceleme: facebook örneği. Kastamonu Üniversitesi İktisadi ve İdari Bilimler Fakültesi Dergisi, 4(2), 42-59.

Fariborzi, E., and Zahedifard, M. (2012). E-mail Marketing: Advantages, disadvantages and improving techniques. International Journal of e-Education, e-Business, e-Management and e-Learning, 2(3), 232.

Fogli, D., Gelfi, N., Giacomin, M., and Guida, G. (2010). A computational model for adapting presentation to content in web interfaces. International Journal on Artificial Intelligence Tools, 19(06), 783-818.

Fux, M., Notı, M., and Myrach, T. (2006). Quality of feedback to e-mail requests an explorative study in alpine tourism destinations in Hitz, M., Sigala, M., Murphy, J. (Eds.): Information and Communication Technology in Tourism, Wien, New York: Springer p: 370.

Gedik, Y. (2020a). Pazarlamada yeni bir pencere. Journal of Business in the Digital Age, 3(1), 63-75.

Gedik, Y. (2020b). E-Posta Pazarlama: Teorik bir bakış. Uluslararası Yönetim Akademisi Dergisi, 3(2), 476-490.

Genç, E. ve Erdoğan, E. (2013). Otel işletmelerinde ilişkisel pazarlama uygulamaları: Zonguldak, Karabük ve Bartın illerinde bir araştırma. Afyon Kocatepe Üniversitesi İktisadi ve İdari Bilimler Fakültesi Dergisi, 15 (2) , 195-216.

Global Dijital Raporu, 2020. https://wearesocial.com/digital-2020. Erişim Tarihi: 30.1.2021

Güçdemir, Y. (2017). Sosyal medya: Halkla ilişkiler, Reklam ve Pazarlama. İstanbul: Derin Yayınları.

Gülten K., (2019). Uzmanından SEO, Ceres Yayınları, İstanbul.

Güzel, T. ve Başaran, Y. (2019). Turizmde kullanılan mobil uygulamalar ve müşteri deneyim etkileşimi. Sivas Interdisipliner Turizm Araştırmaları Dergisi, 4, 15-32.

Haşıloğlu, S. B., ve Karaman, A. (2006). Antalya bölgesindeki konaklama işletmelerinin İnternet'teki faaliyetleri üzerine bir uygulama. Selçuk Üniversitesi Sosyal Bilimler MYO Dergisi, 9/1-2, 133-151.

Hsu, Y. L. (2012). Facebook as international eMarketing strategy of Taiwan hotels. International journal of Hospitality Management, 31/3, 972-980.

Huang, E. and Chang, C.A. (2014). Case studies of implementation of interactive e-health tools on hospital web sites, e-Service.A Journal of Electronic Services in the Public and Private Sectors, 9/2: 46-61.

Huang, M. H. and Wang, E. T. (2013). "Marketing is from mars, it is from venus: aligning the worldviews for firm performance", Decision Sciences, 44(1): 87-125.

Hudák, M., Kianičková, E., and Madleňák, R. (2017). The importance of e-mail marketing in e-commerce. Procedia Engineering, 192, 342-347. 
O. Özışık Yapıcı - A. T. Özden 13/3 (2021) 2129-2145

Istvanic, M., Milic, D. C. \& Krpic, Z. (2017). Digital marketing in the business environment. International Journal of Electrical and Computer Engineering Systems, 8(2), 67-75.

İnce, İ. ve Doğantan, E. (2020). Otel yöneticileri perspektifinden dijital pazarlama. Anadolu Üniversitesi Isşletme Fakültesi Dergisi, 2/1, 13-26.

Kalpaklığlu, N., Ü. (2015). Bir pazarlama iletişimi unsuru olarak e-wom'un turizm ürünleri tercihine etkisi. Maltepe Üniversitesi İletişim Fakültesi Dergisi, 2/1, 66-90.

Kallier, S. (2017). The Influence of Real-time Marketing Campaigns of Retailers on Consumer Purchase Behavior, International Review of Management and Marketing, 2017, 7(3), 126-133.

Kannan, P. (2017). Digital marketing: A framework, review and research agenda, International Journal of Research in Marketing, 34(1): 22-45.

Karabağ, S. F., Özgen, M. H. ve Özgen, H. (2010). Bir iletişim aracı olarak web siteleri: Türkiye'deki otel web sitelerinin etkinliği üzerine bir araştırma. Öneri, 9(33), 17-32.

Kaplan, A. M., and Haenlein, M. (2010). Users of the world, unite! The challenges and opportunities of Social Media. Business Horizons, 53(1), 59-68.

Karaca, Ş. ve Gülmez, M. (2010), Mobil Pazarlama: Kavramsal Bir Değerlendirme. Akademik Yaklaşımlar Dergisi. $1(1), 69-81$.

Karamustafa, K. ve Öz, M. (2010). Türkiye'deki konaklama işletmelerinin web sitelerinde yer verilen faktörlerin başarımı. Eskişehir Osmangazi Üniversitesi İ̈BF Dergisi, 5(2), 189-218

Karasar, N. (2005). Bilimsel Araştırma Yöntemleri (15. Baskı). Nobel Yayın No: 068, Ankara.

Kaur, G., (2017). The Importance of digital marketıng in the tourısm industry. International Journal of Research - Granthaalayah, 5/6, 72-77.

Kheiri, J. and Nasihatkon, B. (2015), Evaluating the effects of social media usage on tourist's behavior based on different phases of travel process. SIT Journal of Management, 5/2, 2.

Kılıç, B., Yozukmaz, N., Yüksel, F., ve Bilici, H. (2017). Turizmde mobil pazarlama: turistlerin mobil pazarlama uygulamalarına karşı tutumları. Balıkesir Üniversitesi Sosyal Bilimler Enstitüsü Dergisi, 20(38), 449-472.

Kırçova, İ. (2012). İnternette Pazarlama, İstanbul: Beta Yayıncıllk.

Kırlar Can, B, Yeşilyurt, H, Lale Sancaktar, C, ve Koçak, N. (2017). Mobil çağda mobil uygulamalar: türkiye'deki yerli otel zincirleri üzerine bir durum tespiti. Journal of Yaşar University, 12(45): 48-59.

Liao, H., R.W. Proctor \& G. Salvendy (2008). Content preparation for cross cultural e-commerce: a review and a model. Behaviour \& Information Technology, 27/1, 43-61.

Li-Hsing, H., Meng-Huang, L., Jui-Chen H. \& Hui-Yi, H. (2010). The application of search engine optimization for internet marketing: An example of the motel websites. Institue of Electrical and Electronic Engineers, $1,380-383$.

Lorente Páramo, Á. J., Hernández García, Á., \& Chaparro Peláez, J. (2021). Modelling e-mail marketing effectiveness-An approach based on the theory of hierarchy-of-effects.

Malaga, R. (2008).Worstpractices in search engine optimization. Communications of the ACM, 51/12, 147-150.

Matzler, K., Pechlaner, H., Abfalter, D., an Wolf, M. (2005). Determinants of response to customer e-mail enquiries to hotels: evidence from Austria. Tourism Management, 26/2, 249-259.

Metin, İ. (2015). Turizm Pazarlamasında Güncel Yaklaşımlar. Burhan Kılıç ve Zafer Öter (Ed.), E-Pazarlama (s.80). İstanbul: Beta Yayınları.

Murphy, J., Olaru, D., Schegg, R., and Frey, S. (2003) The Bandwagon Effect: Swiss Hotels Web-site and E-mail Management, Cornell Hotel and Restaurant Administration Quarterly, February, ss.71-87.

O'Connor, P. (2008). E-mail marketing by international hotel chains: An industry-practices update. Cornell Hospitality Quarterly, 49/1, 42-52. 


\section{O. Özışık Yapıcı - A. T. Özden 13/3 (2021) 2129-2145}

Özgen, E., ve Doymuş, H. (2013). Sosyal medya pazarlamasında farklılaştırıcı bir unsur olarak içerik yönetimi konusuna iletişimsel bir yaklaşım. AJIT-e: Bilişim Teknolojileri Online Dergisi, 4/10, 91-103.

Özkan, N. ve Ulama, Ş. (2018). Marmara bölgesindeki 4 ve 5 yıldızlı konaklama işletmelerinin web sitelerinin değerlendirilmesi. Journal of Gastronomy and Travel Research, 2/2, 13-33.

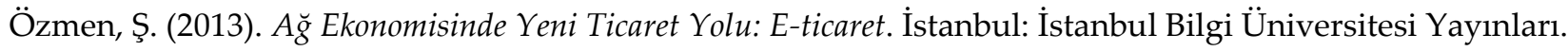

Pan, B. (2015). The power of the search engine ranking for tourist destinations. Tourism Management, 47, 79-87.

Pan, B., Xiang, Z., Law, R. and Fesenmaier, D. R. (2011). The Dynamics of search engine marketing for tourist destinations. Journal of Travel Research, 50/4, 365-377.

Paraskevas, A., Katsogridakis, I., Law, R. and Buhalis, D. (2011). Search engine marketing: Transforming search engines into hotel distribution channels. Cornell Hospitality Quarterly, 52/2, 200-208.

Petrescu, M., and Korgaonkar, P. (2011). Viral advertising: Definitional review and synthesis. Journal of Internet Commerce, 10/3, 208-226.

Pınar, İ. (2013). Mobil Pazarlama ve E-Turizm, Gözlem Gazetesi, https://www.gozlemgazetesi.com/HaberDetay/251/111669/mobil-pazarlama-ve-e-turizm.html. Erişim Tarihi:21.02.2021

Russell, J. (2010). Evaluate the effectiveness of social media marketing on hotels. Hospitality Management Review Student Journal at Sheffield Hallam University, 1.

Saçkes, E. ve Doğdubay, M. (2019). Konaklama işletmelerinin pazarlamasında mobil teknolojinin kullanımı. Global Journal of Economics and Business Studies, 8/16, 183-195.

Sarı, Y. ve Kozak, M. (2005), Turizm işletmelerinde doğrudan pazarlama çabaları kapsamında bilgi teknolojilerinin kullanımı, İktisadi ve İdari Bilimler Dergisi, 19/1, 361.

Schegg, R., Murphy, J., and Leuenberger, R. (2003). Five-star treatment? E-mail customer service by international luxury hotels. Information Technology \& Tourism, 6/2, 99-112.

Suh, K.S. and S. Chang (2006). User interfaces and consumer perceptions of online stores: The role of tlepresence. Behaviour \& Information Technology, 25/2, 99-113.

Sürücü, Ö., ve Bayram, A. T. (2016). Mobil pazarlama ve turizmde mobil teknolojilerin kullanımı. Journal of International Social Research, 9/42. 2024-2032.

Şahin, B., ve Cıbıt, Ö. (2016). Mobil pazarlama ve online alışveriş ilişkisine yönelik tüketici algıları: seyahat acentası müşterilerine yönelik bir araştırma. Uluslararası Sosyal Araştırmalar Dergisi, 9/44, 1221-1231.

Şanlıöz, K., Dilek, E. ve Koçak, N. (2013). Değişen dünya, dönüşen pazarlama: Türkiye turizm sektöründen öncü bir mobil uygulama örneği. Anatolia: Turizm Araştırmaları Dergisi, 24/2, 250-260.

Türker, G. Ö., ve Türker, A. (2017). Çağdaş pazarlama iletişim kanallarının butik oteller tarafından kullanım etkinliğinin analizi. Uluslararası Sosyal Araştırmalar Dergisi,10(50), 776-787.

Unur, K., Erdem, A. ve Kızılcık, O. (2017). Adana ilinde faaliyet gösteren dört ve beş yıldızlı otel işletmelerinin web site içeriklerinin incelenmesine yönelik bir araştırma. Uluslararası Sosyal Bilimler Sempozyumu, Kahramanmaraş, 105-119.

Vyas, C. (2019). Evaluating state tourism web sites using search engine optimization tool. Tourism Management, 73, 64-70.

Wang, D., Xiang, Z., Law, R. and Pui Ki, T. (2016). Assessing hotel-related smartphone apps using online reviews. Journal of Hospitality Marketing \& Management 25, 291-313.

We Are Social. https://wearesocial.com/ Erişim Tarihi: 17.02.2021

Yalçın, M. ve Bahar, O. (2019). Seyahat acentelerinin web sitelerinin betimsel analizi ve tüketici değerlendirmesi. Uluslararası Toplum Araştırmaları Dergisi. 11/18, 286-320. 
O. Özışık Yapıcı - A. T. Özden 13/3 (2021) 2129-2145

Yalçınkaya, N. (2018). Türkiye'deki siyasi partilerin dijital pazarlama kanallarını kullanımı. Yönetim ve Ekonomi, 25/1, 199-216.

Yang, K., Min, J. H., and Garza-Baker, K. (2019). Post-stay email marketing implications for the hotel industry: Role of email features, attitude, revisit intention and leisure involvement level. Journal of Vacation Marketing, 25/4, 405-417.

Yanık, A. (2017). Otel web tasarımı ve web bağlılığının çevrimiçi satın alma niyetine etkisi: Dubai'deki iş gezginleri üzerine bir araştırma. International Review of Economics and Management. 5/3, 69-83.

Yavuz, M. ve Hasekï, M. (2012). Konaklama işletmelerinde e-pazarlama uygulamaları: e-medya araçları temelinde bir model önerisi. Çă̆ Üniversitesi Sosyal Bilimler Dergisi, 9 (2) , 116-137.

Yıldız, E. ve Davutoğlu, A. N. (2020). Turizm 4.0'dan gastronomi 4.0'a giden yolda: Geleceğin restoranları ve yönetimi. Akademik Sosyal Araştırmalar Dergisi, 8/109, s:301-318.

Yılmaz, Ö. D. (2017). Türkiye'deki yerli ve yabancı otel zincirlerine yönelik web tabanlı içerik analizi. Journal of Yaşar University, 12/48, 237-248.

Zengin, B., ve Arıcı, S. Konaklama işletmelerinin sosyal medya kullanım şekillerinin tüketici satın alma niyeti üzerindeki etkisi. ISARDER- Turk, 9/4, 375-399.

Zeylan, T. ve Öztürk, G. (2019). Türkiye'deki seyahat acenteleri açısından mobil pazarlamanın önemi. Uluslararası Halkla İlişkiler ve Reklam Çalışmaları Dergisi, 2/2, 73-95. 